\title{
X-EDGE X-RAY FLUORESCENCE ANALYSIS FOR ACTINIDE AND HEAVY ELEIENTS SOLUTION CONCENTRATION MEASUREMENTS
}

\author{
David C. Camp
}

\section{This paper was prepared for submittal to Denver X-Ray Conference \\ Denver, Colorado \\ Hugtot $1-3,1984$ \\ $0-7 / 30-5 / 3 / 84$}

July 1984

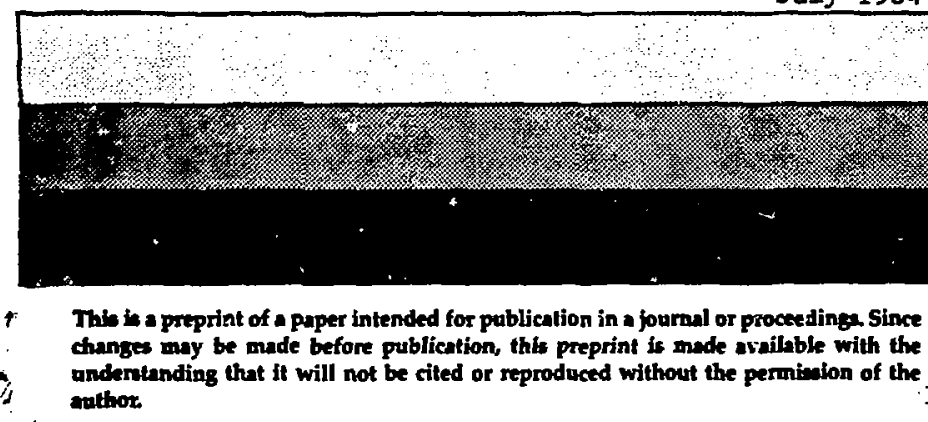
anthor.

\section{DISCLAIMER}

This report was prepared as an scoount of wort sponsored by an agency of the United States Government. Neither the United States Government wor any agency thereof, nor any of their

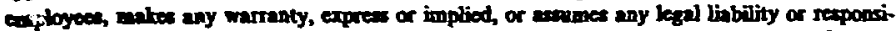

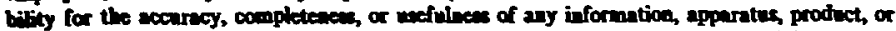

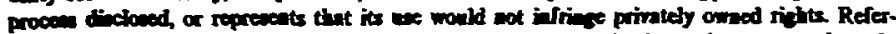

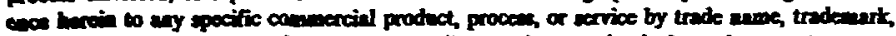

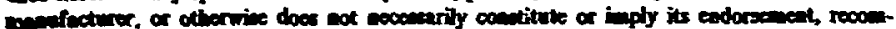

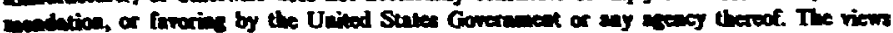

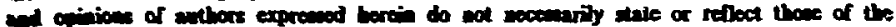

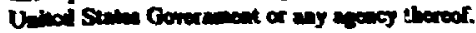
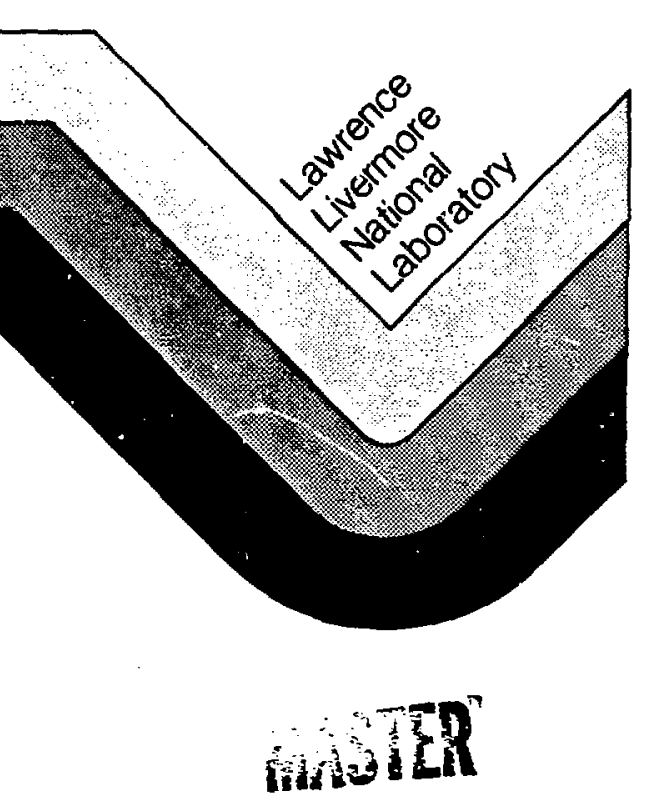


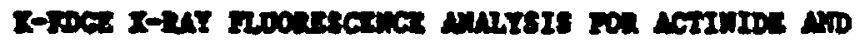

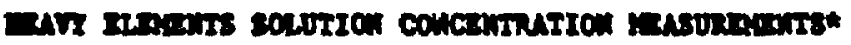

\author{
David C. Gep \\ Larrence Livernore Matioun Laboratory \\ Datveralty of Callfornia \\ Ilverwore, ch 94550
}

\title{
IIIRODUCTIOA
}

There are currently no plans for the concrelal reproceselns of nuclear fuel in the U.S. Thit is not the case in Jepan, England, France, Geranny, or the USSR. The U.S. does, horever, Include the reprocese ing of spent nuclear fuel as a part of 1tn defense prograns. The office of Safeguards and Security of DOE'. Defence Prograns has funded the developnent and optinleation of numerous nondestructive analysis techniques including $k$-edge $x$-ray fluorescence anelysib. This paper reviewe sone if the implenentation efforts resulting from $R$ SD aupported by that office.

In 1979, the concept ${ }^{2}$ of using K-edge x-ray fluorescence analyels ( $K$ XRFA) for the andiyels of actinide oolution concentrations was first presented. K XRFA using sall radloactive Co-57 sources has been shown to be a practical way to measure actinlde colution concentrations in offI1ne, at-line, or on-1ine conf1gurations. The experinental ethodology 18 elegant and the hardware 1s simple. With 11ttie or no nodifications, the same configurations can be used to mesure solution concentrations of heavy elearents. Since that f1rst paper, a nunber of advancenats heve occurred and wil be briefly reviewed here. Because of the brevity of this paper, the 1nterested reader aust seak detalls in the references.

Heavy element herein 1o defined as an element with atomic number $(z)$ 8reater than 72, hafalum. The $\mathrm{K}$ absorption edge, Kab, for af $1865.3 \mathrm{keV}$; for $B 1(Z-83)$ it is $90.5 \mathrm{keV}$. Elenente $\mathrm{PO}, \Delta t, \mathrm{Bn}, \mathrm{Fr}, \mathrm{Rn}$, and $\mathrm{Ac}(2-8 \mathrm{~h}-$ 89) are rarely of 1ndustrial or trace interest. Thorlin $(z-90)$ begins the actinide aer1es and 1ts $\mathrm{kab}$ is $109.6 \mathrm{kV}$; and $\mathrm{Pu}$, the last anjor acEInide of reproceseing interest, bes a Kab of $121.72 \mathrm{keV}$. The Tal $x$-ray energies of Hf to $\mathrm{B1}, 72<2683$, go fro 55.8 to $77.1 \mathrm{keV}$, whle for $\mathrm{Th}, \mathrm{U}$, Fp. and Pu they extend from 93.35 to $103.75 \mathrm{keV}$. These are high werey $x$-raye and are very penetratios. In order to create $x$ raye of the elowents uf to $\mathrm{Pu}_{\mathrm{p}} 72<2694$, an excitation voltage in excess of $122 \mathrm{keV}$ is needed. Such bigh energies can be obtalned with asestve and expenaive x-ray machines: bonver, radionctive Co-57 aite a 122.05-keV gune ray 1deally sutted to exclie all of these hears elcient $x$ rays. It's avallable in high specific activities. which wane very andi cources can be Work perforned under the sueplees of the D.S. Departent of Enervy by the Iawrence Ifverwore mational Laboratory under contract B-7405-206-18. 


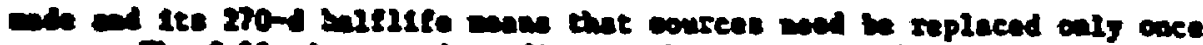

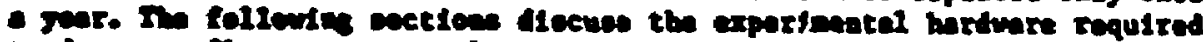

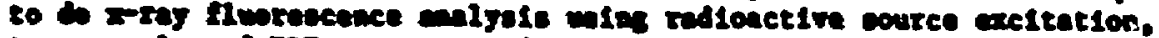

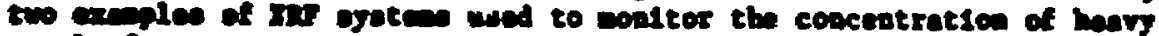

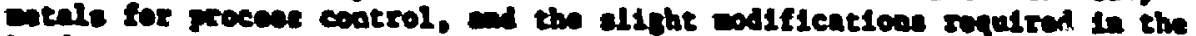

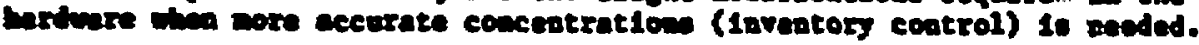

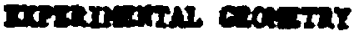

Figure 1 bhom the cophluticated, jet clezant peontry that sllow $K$

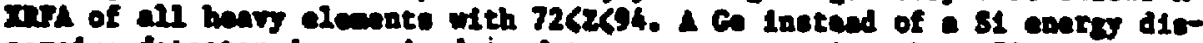
perolve btector is required to detect m-ras energlec above 50 kap. Sufflelent shseldin is required between detector and exciter sources and the exciting radietion but be collinated, An up-lookting detector allow the andyeis of borizontel plpee (oo-1ine); or if we rotete this ascenbly 50\%, right-angle detector can analyse colution in teat tubes or in opecialiy constructed celle (off-11be or at-11ne).

The ngaten shown in Fig. $1 \mathrm{me}$ dealgned ${ }^{2}$ to deternine the concentration of solutione conteining pure $U_{\text {, pure }} \mathrm{Pu}$, or Eixturea of $\mathrm{D}+\mathrm{Pu}$. The top-view drawing thows two linear actuators that Incert two ohutters on comand. The front ohutter eclipses the exciter sources so that any radioactivity in the colution can be seasured; the rear shutter conposed of $1 \mathrm{Fw}$ Cd or Rh attenuates an intense 59.5-keV gana ray from the decay of fin, de dughter activity of Pu-241. The purpose of the third, highly collinated, Co-57 source will be described below. The physical olze of the entire source-collinator and detector shielding assembly is 3 inches In dianeter by $2 \mathrm{In}$. long, which is constderably smaller and less expensive than an $x$-ray machine. More laportantly, the astembly can be located anywhere the detector can and if there 1s no radiosctivity in the colution, netther shutter is required. Industrial environments are often host1le, thus the detector can be located renote fron the supporting computer-based electronics that operate the shutters and record the spectral data. Minor variation of this geometry will be described when the X XRPA syatens developed over the past several yearo are described.

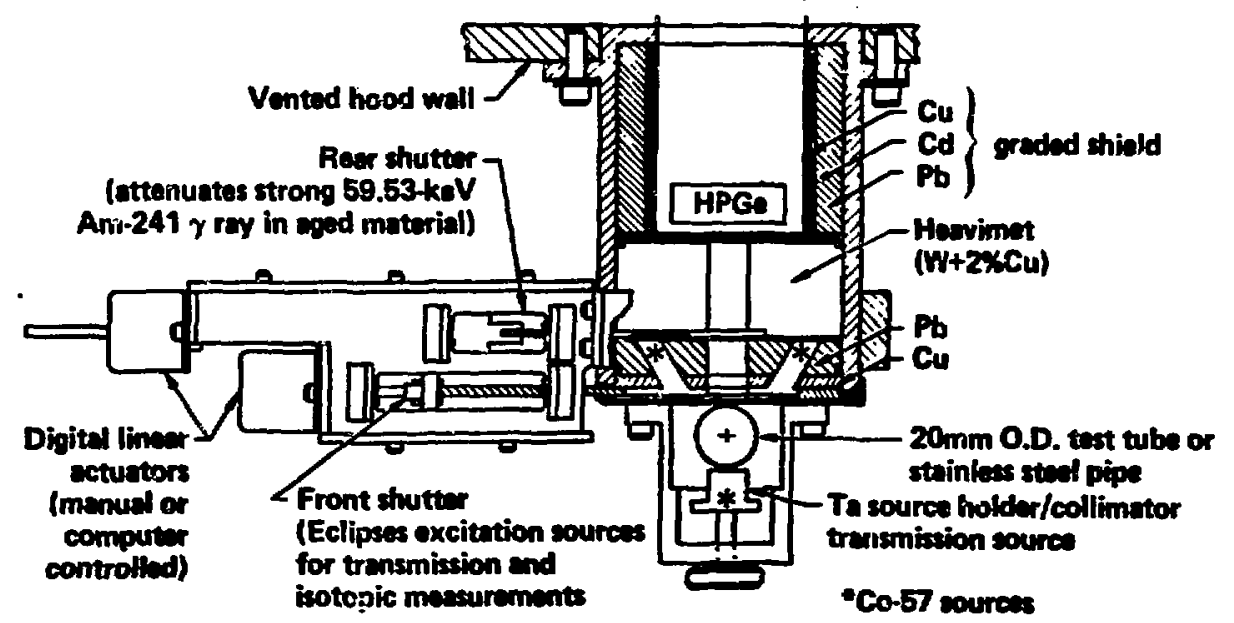

718. 1. Top rien of one exclter-detector collieation asaenbly. Wote the shutters and the wery collinated 3rd Co-57 cource oppontte the detector. 


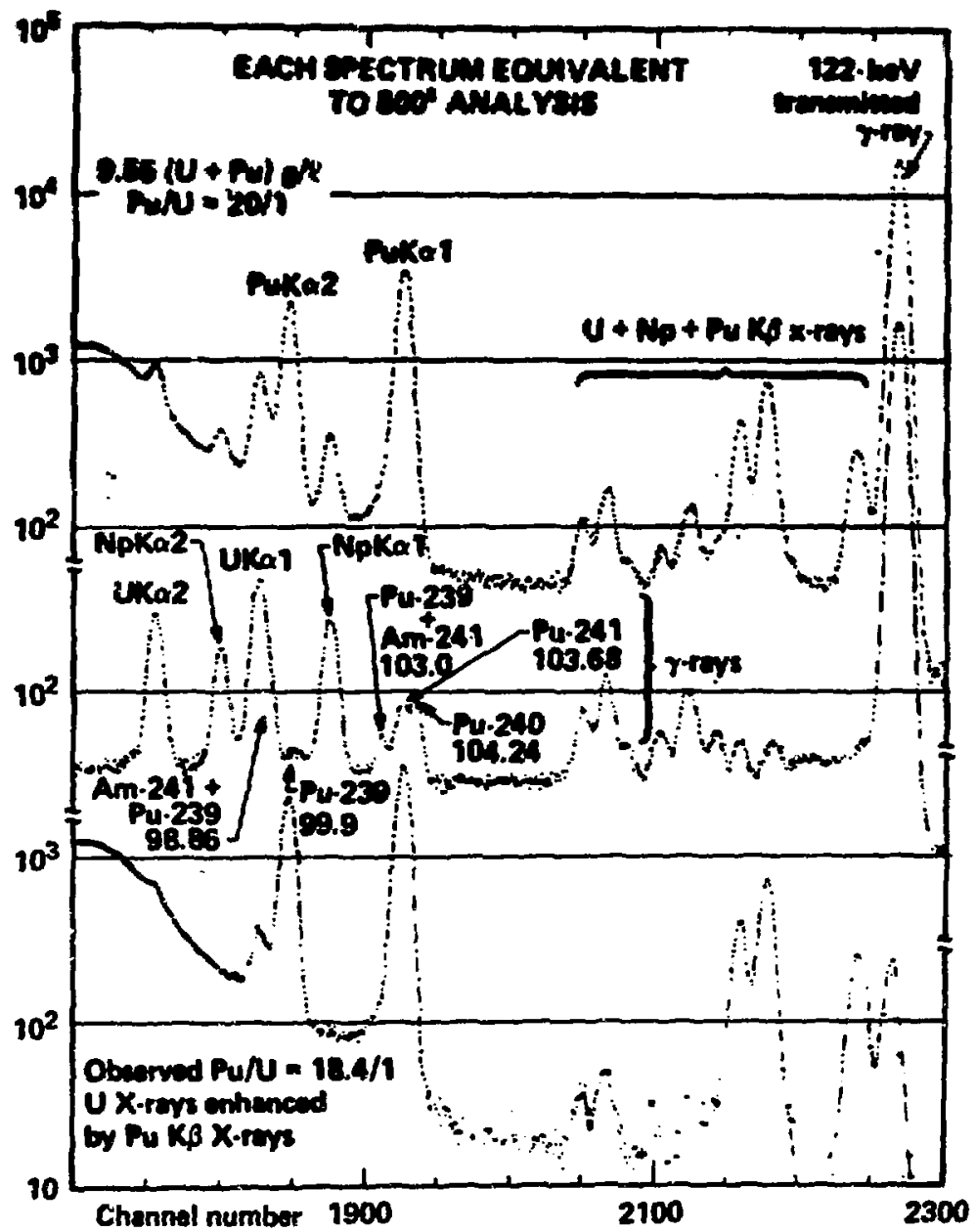

F1g. 2. Partiel XRF, paselve, and net epectra from a alxed UH solution.

Figure 2 thow a 500s XRF spectrue (top) of a 20/1::Pu/U wixture sith $9.55 \mathrm{giJ}+\mathrm{Pu} / 1$. The center opectrun is taken with the front shutter closed co that the enitted radioactivity is counted. The 0 and Np $x$ rays result froe the alpha decay of Pu and Am; the gama rays reault from the muclear decay of varlout Pu 1sotopes. Their contribution is renoved by subtracting the passive from the active opectrum to field the net fluoresced zray epectrun (botton). Note that the observed Pu/O ratio of 18.4 is less than the stated 20/1 value. The $\mathrm{U}$ I rays are enhanced by the enteston of Pu KB $x$ rays and a strong 129 keV Ru-239 gama rey withth the solution.

Since the inside lining of the detector collinator is $\mathrm{cd}$ or th, Ite

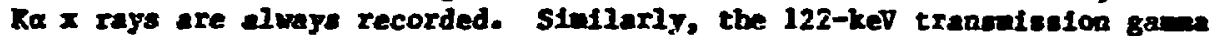
ray 1s elways recorded. Thus, the Cd $X_{0}$ and 122-keV peake are weed to zero and gain stabilize tbe fulse height analysts syste against voltage shifte or galn drifte durins accunilation of elther the actire or pasefve spectre. This enoure accurate quatitative data from their difference. 


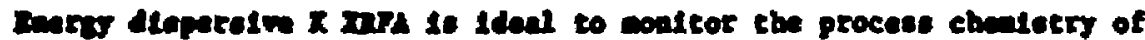

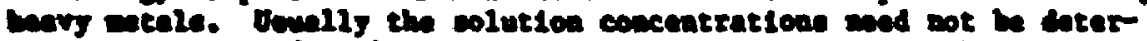

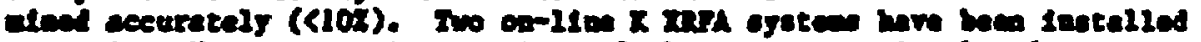

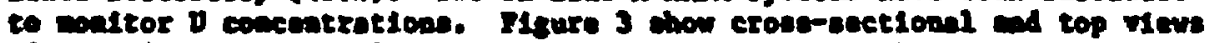

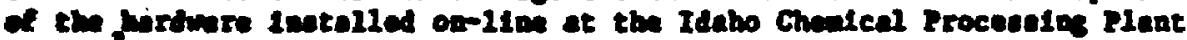

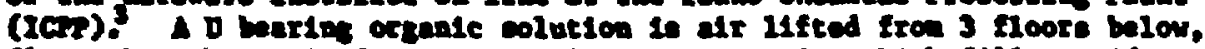
flem through en alr de-entratnor Into a reastrolr, wich flila a elde

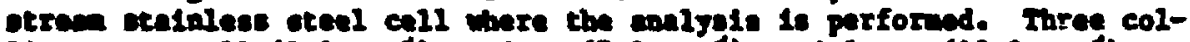

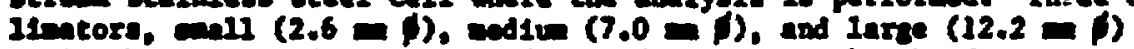
Ifnte the sount of fiseion product radiation ceen by the datector. The entire aseanbly is enclosed in a lead onclosure, roof and aldes.

Two Co-57 sources are Iocated at the ande of the two foot-10ns rods (top v1ew). These rode allow source chunges without disasecubly of the lead house. The two ohuttare are computer controlled; the inoer one eclipese the exciter sourcas so that pasalve fiseion product activity cen be masured; the outer one Inserte a Ni-coated, 5-ail thick, U foll that is used to periodically conitor ajete performace, or callbrate the syaten when new sources are installed.

F1gure 4 shows a 500. 11vetine XRF spectrum of a 937 dodecane plus 77 tributylphosphete (TBP) containing $5 \mathrm{~g} / \mathrm{I}$ using the medium collinator with two 50 a CI Co-57 exciter sources. The U concentratione are deterulred by ratiolng the net $\mathrm{Kal} x$-ray area (KRal) to the gross incoherent (GI) ares. This ratio 1s Indepeadent of the Co-57 half life and only ilghtly cenoltive $(\langle 3 \%)$ to variations in the organic matrix. Normally. opent nuclear fuel is reprocensed in long compaigns, hence fission product level. reach an equilibriun value. After the appropriate sized colIInator is chosen, the activity level need be measured only once/hr. If fiesion product activity within the GI window (shutter closed) 18 less than 47 of the butter open GI value, then it 1s 1gaored. Otherwise, the Mal/GI ratio is obtained from the (active - pasive) difference spectrum. U concentration resulte are printed every 10 in.; then each hour 5 or 6 reaults are listed along with a calculated mean value for the past hour. Finally, once each day the past 24 hourly nean values are 11sted. The Cd ke and i22-keV coherent scatter peake are used to otabilize the spectrum.

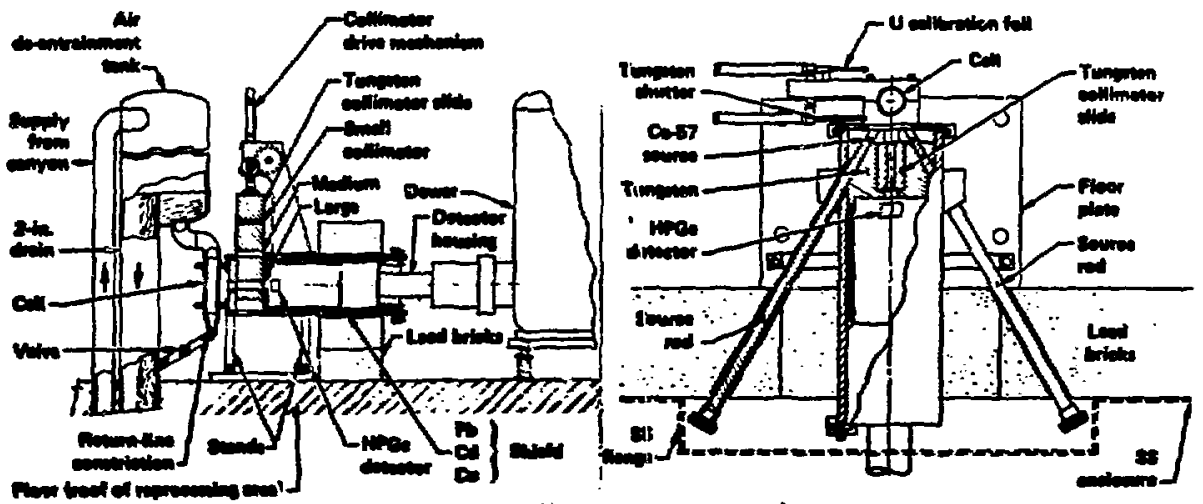

F18. 3. Crose wetion and top view of the ICF or-line $x$ XTA hardware. One of three different alse collimtore Iinte fisolon product count rate. The low rods atlow cource change dithont disasembly of the Po enclosure. 


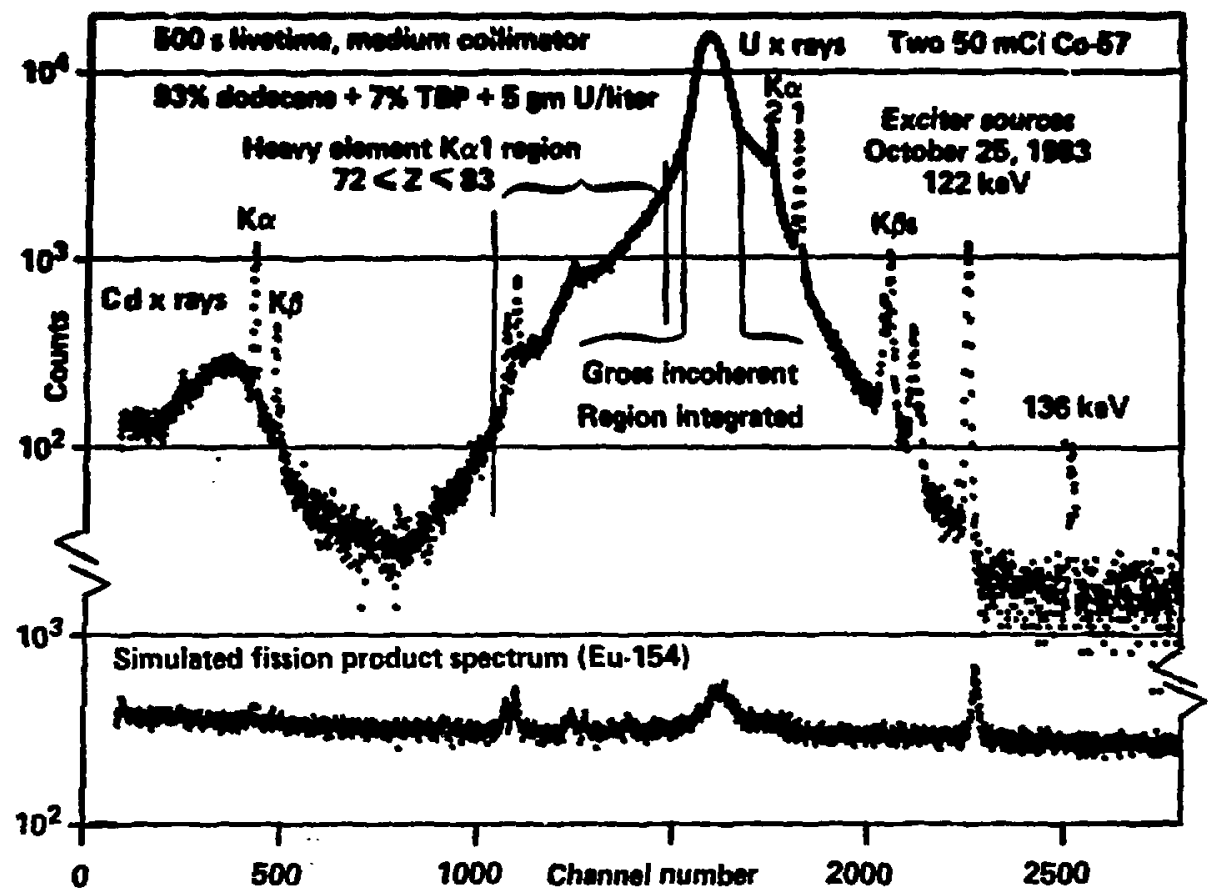

F1g. 4. XRFA of a $5 \mathrm{gJ} / 1$ organic solution as measured thru a steel cell. The region where the $\mathrm{Kal} \times$ rays occur for heavy metals is thown. The simulated fission background was recorded with the front shutter closed.

Figure 4 Indicates the region where the $R a l \times$ ray for the heavy elements occur. The background for this region is about the sane as that for the region in which the actinide $x$ rays fall. However, there is some loss in sensitivity. The fluorescence effictency will decrease we go to lower $\mathrm{Z}$ elements because of the Increasing separation between the 122keV exclting radiation energy and the 90- to 65-kev binding energies of the heavy wetals, B1 to Hf. In fact, for Bf, the required analyeis tine 1s bout 300 a to obtain 17 counting statistics on a solution containing $25 \mathrm{~g}$ Hf/l compared to only 100 sor Pu. A $25 \mathrm{gAu} / \mathrm{l}$ solution would only require 200 s to obtain 17 counting statistics. The tine required tc obtain $10 \%$ counting statistics on $1 / 1$ solution would be 80 for Hf and 55 - for Au. The ininum concentrations detectable by the $R$ XRFA nethodology deacribed in this paper approuches 10-20 parts per allilon (ppi). 50 ppit can be neasured to reasonable accuractes $(-37)$ in 1 to 3 hours.

The first on-1ine XRF assebblies were installed on-1ine in 1981 at Allied General Ruclear Services plant in Barmell, SC (non closed). Solutions were flowed through steel cells, the 0 x-rays excited by Co-57, and the Mal/GI method used to obtain concentrations. Figure 5 show the first on-1ine, near-renl tine, 0 concentration results ever reported.4

\section{INVENTORY CONTROL COACEMTRATIOAS}

An sentioned above, the Ral/GI nethod is cofficiently accurate to 


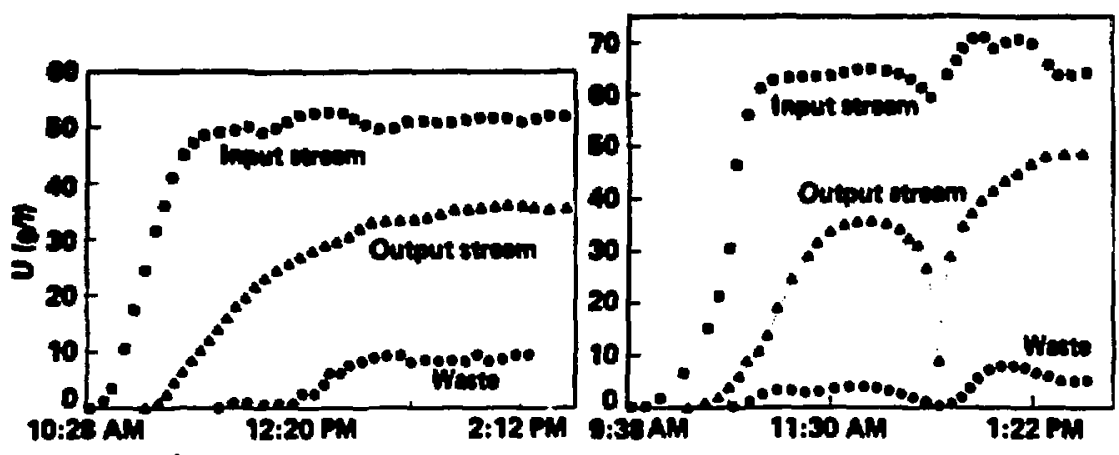

F1E. 5. The left traph show reulte from input, output, and waste etreans operating norwily; the rizht plot show data reported when the Input strea ma temporar11y blocked. The blockage was loediately detected, comunicated to the control room; then the atrean was reopened.

be wed when nonitoring the concentration of one or wore heavy wetals in their process chenistry. The ratio eliminates the ever decreasing Co-57 source intensity due to 1ts decay, and there is only the need to change the radloactive sources once per year. In the event that the concentration needs to be known wore accurately (defined here as leas than 0.57 ), then the $\mathrm{KRal} / \mathrm{GI}$ iethodology is not sufficlently accurate。 Nuclear safeguards aterlal accountablifty has such a réquirement; and it can be met using $x$-ray fluorescence analysis technique, but does not require slight modification: in the already elegant experimental hardware.

In the chenical process of heavy netals and in the reprocessing of nuclear fuels, the process chemistry is not able to control exactly the colution temperature, acid molarity, anion or cation content, or the extent of aqueous or organic inpurities. Variations in any or all of these paraneters cause density changes in the solution containing the heavy etal of interest. As the density increases, z-ray celf-absorption increases and the measured $x$-ray Intensity, KKal will decrease. Meanwhile, as density increases the Compton scattered peak, GI, will increase; hence, the ratio $\mathrm{MRal} / \mathrm{GI}$ wilI decrease. This was confirwed in earlier work.5 So in fact, there are really two unknowns, solution concentration and deneity. Bowever, the earlier work ${ }^{5}$ sowed that transmission of the coherently acattered 122-keV radiation also decreased as the density 1ncreased. So elemental concentration is proportional to $\mathrm{Mal} / \mathrm{p}$; the colution trangelarisity is proportional to $\mathrm{T}(122) / \mathrm{p}$, and then perhaps their ratio (raal/p)/(T(122)/p) will be independent of density $(p)$.

This is exactly what happens. Heary elenent are usully dissolved In aqueous or organic colutions, which conta1n $B, C, H, O$, and other low 2 elewents such as $A 1$. F or $S$ neceseary to curtonize the process cheaistry. The ans absorption coefficients $(\mu)$ of these light elements are all nearly equal at $100 \mathrm{keV}$ (the vielnity of the $U$ and Pu Ral $x$ rays); and nore inportantiy, the ratios of wa at 120 to $100 \mathrm{keV}$ differ by lese than $3.5 \%$ fron $B$ to S. Since the heavy metal concentrations are alwaye beins neasured in solutions, variations in the alnor aqueow or organic inpuritses or light elewent adistures do not algnificantly alter the ecatterins, and hence the transulesion. The relevant anes abeorption coefficteate for a selected few of the $10 \mathrm{~m} \mathbf{2}$ elenente are shom in Iable 1.

$$
-6-
$$




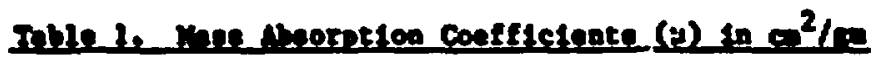

\begin{tabular}{|c|c|c|c|c|}
\hline $\begin{array}{l}\text { Hement } \\
\text { orbel }\end{array}$ & 2 & $100 \mathrm{keV}$ & $120 \mathrm{kes}$ & $\frac{\mu}{\mu(120)}$ \\
\hline $\mathbf{n}$ & 1 & 0.284 & 0.280 & 0.952 \\
\hline $\begin{array}{l}c \\
11 \\
0 \\
1 \\
1 \\
\end{array}$ & $\begin{array}{l}6 \\
7 \\
8 \\
9 \\
13 \\
0 \\
16\end{array}$ & $\begin{array}{l}0.151 \\
0.153 \\
0.155 \\
0.149 \\
0.170 \\
\text { (men Including } \\
0.201\end{array}$ & $\begin{array}{l}0.145 \\
0.146 \\
0.147 \\
0.140 \\
0.153 \\
0 \& 5) \\
0.175\end{array}$ & $\begin{array}{l}0.960 \\
0.954 \\
0.948 \\
0.940 \\
0.900 \\
0.940 \pm 0.024 \\
0.871\end{array}$ \\
\hline & & (Ean Including & $f(s)$ & $0.932 \pm 0 \quad 033$ \\
\hline
\end{tabular}

In effect, the change in density as masured by 122-keV transenteaton 1s quantitatively representative of tranoniseion changes in the actinide $x$-ray region. So Mal/T(122) is Independent of density for $U$ and Pu. This explains the need for the third, highly collineted, Co-57 source that is located opposite the detectof and was antioned above. It does fluoresce the solution, but only $10^{-4}$ as ach as the exciter sources. The third source allows actinide solution concentrations to be weasured Independent of stream denatty and minor 11ght element matrix Impurities.

The exciter-detector collimation assembly shown In F1g. 1 was developed as an off-11ne, $K$ XRFA aystem for Savannah RIver's Pu reprocessing Plant in 1981. Technician operatore withdraw solution samples into cmall plastic test tubes from any of 34 different prosess or product storage tanks. These amples are transported to the $K$ XRFA syctem and placed in between the exciting and transmission sources as show in Fig. 1. A renote terminal links the XRFA syatem to a computer and disk-based FHA, that begins the anslysis autonatically, once seven sinple questions are answerad on a renote terminal. If the need is only for process control Information, only an active fluorescence neasurenent is nade. If Instead an accountability maasurenent 1s desired, then the passive radioactivity spectrum nust be recorded for the sane ilfetine as the active analysis, and the concentration deternined from the uctive - passive spectrun. If both $U$ and Pu concentration are desired, then regardless of the analysis purpose, both active and paselve rectra mut be recorded to renove the contribution of $\mathrm{D}$ r-ray intenalty that cones from the alphe decays of $\mathrm{Pu}$.

The use of ases produced plastic test tubes sth their variable wall thicknesses and dianeters loads to a liwitation of the ultiante accuracy obtainable with this systen. As a reault of this and the steady need to make accountability grade measurenents $\left(\left\langle 0.5 x^{\prime}\right)\right.$; the next syste ${ }^{6}$ was designed to be operated at-11ne. That is, nolutlons are drawn Into a precision achined, stainless steel cell. The cell is located between the exciter and transulasion cources as beforw. In addition, a third atr controlled shutter wan added which can Ineert a ki-conted 0 foll be' ind the cell. It is used to monitor gyoten performance and to facilitace updating the calibration equations when the Co-57 sources are changed.

The ninimu detectable concentrations of Fu weins toro $10 \mathrm{mCl}$ cour. - standard 12- deep, BPCe decector with 500 eV recolution (Fini) at 122 keV with $0.48-$ in detector collínation and 0.75 -in inolde diseter steel cell in a 1000 aneljels is $0.05 \% / 1$. This corresponde to a count rate

$$
-7 \text { - }
$$




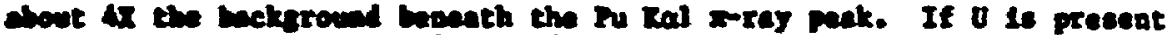
In the colutice, then pu $(00.05 / / 1)$ would ot2li be detectoble at levele 10002 Iees then the 0 concontration becaue the Pu $x$ raye fall above chave of 0 . On the other hand, bacouse the acatterise background is

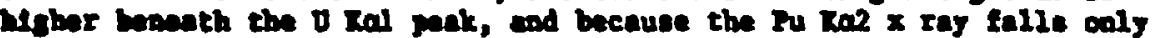

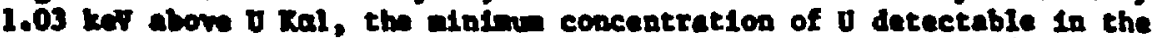

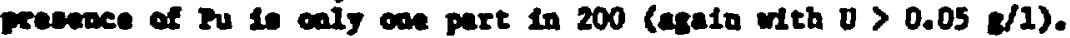

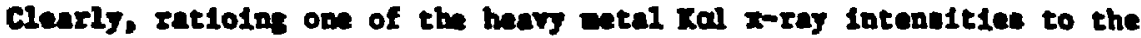
tranalsalon intensity at $122 \mathrm{kav}$ would not be a good a correction for colution donstiy variation as it is for the ectinide xa x-ray reg10n. If very accurate concentrations were meded fer one of the heavy atals, say gold, then It would be beter to use a To foll behind the cell Instead of - transelsesion cource. The Au ral to In kal ratlo would correct for both colution denalty variations and cource exciter helf life. If accurate concentrations are not needed, then the $\mathrm{Mal}(\mathrm{z}) / \mathrm{GI}$ correcte for cource decey, and wo shutere are needed $1 f$ there 1 s no solution radioactivity.

\section{SUMHARY}

The advantages of using Co-57 as an exicter for $\mathrm{K}$ XRFA Include:

- a compact design thet requires no $x$-ray tubes;

- the exciter-detector assembly locates remote from support elactronlcs;

- on-line, at-line, or off-line conflgurations for monitor/measurements;

- eystens that can be run by semi-skiljed technicians, once programmed;

- and operated via remote terninals with results sent to control rooms;

- heavy element concentrations that are measurable thru industrial pipes

- Independent of minor changes in solution matrix or cource half life

- with concentretion result $B$ reported in near-real-time;

- a dynamic range of measurable concentrations that 18 greater than $10^{4}$;

- measurement times that are reaconable even at 1 gram/liter; and

- for nuclear safeguards, it provides the $<0.5 \%$ accuracy required by DOE for the accountability of $\mathrm{U}, \mathrm{Pu}$, or both, once the system $1 \mathrm{~s}$ calibrated.

\section{REFERENCES}

1. D. C. Camp and W. D. Ruhter, Nondentructive, Energy Dispersive X-Ray Fluorescence Analyole of Actinide Stream Concentrations from Reprocessed Nuclear Fuel, Adv. In X-Ray snalys1s, 23:153 (1980).

2. D. C. Camp, W. D. Ruhter, and K. W. Kaclurdo, Deternination of Act1nide Process and Product Stream Concentrations off-Iine or at-Line by Energy Dispersive X-Ray Fluorescence Analysis, Proc. of 3rd ESARDA Syaposiue on Safeguarde and Huclear Material Manageaent, Karlsruhe, F. R. Gernany, 6-8 May 1981, P. 155-159 (1981).

3. D. C. Canp, W. D. Kuhter, C. E. Johncon, and T. C. P1per, Rear-RealTine Actinide Concentrations VIa Energy Dieperalve XRFA for Proceas Control and Material Accountability, Proc. of An. Fuc. Soc. and Inat. Nuc. Mat. Mgrs. Conf. (1984) and UCRL-90037 (1983).

4. B. C. Benderson, R. S. Lee, G. A. Huff, and D. C. Canp, Inersy Dispersive XRFA for On-LIne 0 Concentration Measurenents. "Analytical Cheiletry in Muclear Technology, ${ }^{*}$. S. Ljon, ed., Ann Arbor Science, p. 253-260 (1982).

5. D. C. Canp, W. D. Ruhter, S. Eenjanin, Hondentruct17e, Enersy Diepersive IRHA of Product Strea Concentrations from reprocessed $\mathrm{LW}$ Fuelo, VCRL-52616, IITL Ieport (1979).

6. R. A. Johns, R. Parry, P. Darter, D. C. Com, W. D. Ruhter, and D. Ec-

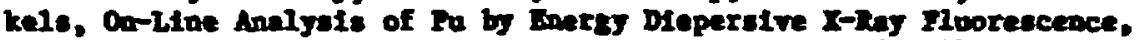
Froc. of 25th Am Mts. of the Innt. Jue. Int. Mira. (19a4).

$$
-8-
$$




\section{DISCLAIMER}

This document was prepared as an account of work sponsored by an ageney of the I'nited Siates Giovernment. Neither the U'nited States Government nor the University of California nor any of their employees, makes any warranty, express or implied, or assumes any lega! liability or responsibility for the accuracy, completeness, or usefulness of any information, apparalus, product, or process disclosed, or represents that its use would not infringe privately onned rights. Reference herein to any specific commercial products, process, or sern ice hy Irade name, trademark, manufacturer, or otherwise, does not necessarily constitute or imply its endersemem, recommendation, or favoring by the ( inited Siates Goversmeni or the L'niversity of California. The views und opinions of authors expressed herein do not necessarily state or reflect those of the ('nited States Government thereof, and shall not be used for advertising or product endorsement purposes. 